\title{
Model Penjadwalan Pengiriman Pasokan pada Strategi Multi- Supplier dengan Variasi Harga dan Lead Time untuk Permintaan Stokastik
}

\author{
Nur Aini Masruroh ${ }^{1 *}$, Anggita Virgiana Prasetyorini ${ }^{1}$
}

\begin{abstract}
Multi-supplier is one of the strategies to minimize holding cost and average stock-out cost as long as to stabilize the supply of raw materials. The common problems that the firms may face when applying the multi-supplier strategy are determining the right schedule and quantity ordered for each supplier. Complexity of the problem increases with the facts that each supplier may have different parameters, demand is uncertain, and the firms' constraints. Thus, this research is done to answer two main objectives: (1) to determine the optimum safety time (minimum raw material inventory) to prevent the stockout due to the demand uncertainty and (2) to determine the right schedule and quantity ordered for each supplier considering the different suppliers parameters: price, lead time, and supply capacity. The problem is modeled in Mixed Integer Linear Programming with total minimum inventory cost as the objective. With the aim of testing the model, a case of multinational company that apply the multi-supplier strategy is used.
\end{abstract}

Keywords: Multi-supplier, mixed integer linear programming, inventory, scheduling, safety time.

\section{Pendahuluan}

Salah satu tantangan dalam supply chain management adalah kemampuan mengontrol jumlah modal yang dimiliki, yang antara lain tersimpan dalam bentuk investasi inventory, baik bahan baku, work in process, maupun produk jadi (Arda dan Hennet [1]). Pengendalian inventory menjadi aktivitas yang sangat penting pada sebuah perusahaan karena biaya inventory dapat mencapai sekitar $20 \%$ hingga $40 \%$ total nilai tahunan (Ganeshan [2]). Salah satu faktor penting dalam pengendalian inventory adalah penentuan safety stock yang tepat. Safety stock adalah sejumlah inventory, khususnya bahan baku, yang dimiliki perusahaan untuk mencegah terjadinya stock out selama waktu pemesanan akibat adanya fluktuasi permintaan dan lead time pemesanan ke supplier. Penentuan tingkat safety stock yang dipengaruhi oleh lead time pemesanan menunjukkan bahwa kemampuan supplier dalam memenuhi pesanan menjadi faktor penting dalam melakukan pengendalian inventory. Hal inilah yang mendorong setiap perusahaan untuk merancang strategi dalam menggantungkan kebutuhan bahan bakunya kepada supplier.

Pada awalnya banyak perusahaan yang menggunakan strategi single-supplier yang memudahkan per-

${ }^{1}$ Fakultas Teknik, Jurusan Teknik Mesin dan Industri, Universitas Gadjah Mada, Jl. Grafika 2, Kampus UGM, Yogyakarta 55281. Email: aini@ugm.ac.id, anggita.prasetyorini@gmail.com.

* Penulis korespondensi usahaan dalam melakukan pengendalian kualitas dan memungkinkan terciptanya hubungan yang dekat antara perusahaan dan supplier. Namun saat ini, strategi tersebut mulai berkembang menjadi multi-supplier, yaitu strategi dimana perusahaan memiliki beberapa supplier yang memasok jenis bahan baku yang sama. Salah satu faktor perubahan tersebut adalah kebutuhan bahan baku yang semakin meningkat seiring dengan meningkatnya permintaan pelanggan yang berakibat pada meningkatnya kebutuhan bahan baku di lantai produksi. Selain itu, penerapan strategi multi-supplier juga didorong oleh kekhawatiran akan beberapa risiko, seperti monopoli harga, keterlambatan pengiriman karena mesin breakdown, demo buruh, keterbatasan kapasitas, hingga variasi lead time (Minner [3], Sawik [4]). Selain itu, membagi order ke beberapa supplier juga dapat mengurangi jumlah safety stock yang harus disediakan, mengurangi cycle stock, serta incremental ordering cost dari order kedua dan selanjutnya menjadi relatif lebih kecil (Thomas and Tyworth[5]). Melalui strategi multi-supplier, diharapkan perusahaan dapat melakukan penghematan biaya dan meningkatkan service level.

Pada beberapa kasus, strategi multi-supplier memang memberikan hasil yang lebih baik karena lebih memberikan jaminan akan ketersediaan bahan baku. Selain itu, strategi multi-supplier dapat menghindari kemungkinan terjadinya monopoli harga dan kualitas oleh supplier. Sebaliknya, strategi ini justru akan membuat supplier saling berlomba untuk memberikan pelayanan terbaik kepada 
perusahaan. Kelebihan strategi multi-supplier juga didukung oleh penelitian yang dilakukan oleh Arda dan Hennet [1], yang memberikan kesimpulan bahwa untuk kasus permintaan pelanggan dan keterlambatan pengiriman dari supplier terjadi secara random, strategi multi-supplier memberikan kemungkinan penghematan biaya yang lebih besar dibandingkan dengan strategi single-supplier.

Masalah yang kemungkinan akan dihadapi dalam penerapan strategi multi-supplier adalah bagaimana menentukan porsi pemesanan yang tepat untuk masing-masing supplier dan merencanakan waktu kedatangan serta kuantitas bahan baku pada setiap pengiriman untuk masing-masing supplier. Perencanaan waktu kedatangan dan kuantitas pengiriman yang tepat harus memperhatikan parameter yang dimiliki oleh supplier, seperti lead time pengiriman, kuantitas pengiriman, dan lot size setiap pengiriman, serta mempertimbangkan batasan dari perusahaan, seperti kapasitas warehouse dan batas minimal inventory yang harus dimiliki perusahaan. Permasalahan akan menjadi lebih kompleks karena perbedaan nilai parameter yang dimiliki oleh setiap supplier. Terkait dengan skala perusahaan, setiap supplier dapat memiliki kapasitas yang berbeda dalam proses produksi, sehingga berpengaruh pada kuantitas serta lot size pengiriman yang berbeda-beda untuk setiap supplier. Selain itu, perbedaan asal negara supplier menyebabkan adanya perbedaan waktu pengiriman sehingga setiap supplier akan memiliki lead time yang berbeda dalam memenuhi pesanan. Faktor lain yang menambah kompleksitas dari penerapan strategi multi-supplier adalah adanya perbedaan harga yang diberikan oleh setiap supplier, walaupun memasok untuk jenis bahan baku yang sama. Terkait dengan perencanaan waktu kedatangan dan kuantitas pengiriman, faktor harga patut mendapat perhatian dalam melakukan pemesanan karena faktor tersebut yang akan mempengaruhi jumlah modal yang tersimpan dalam bentuk inventory di warehouse.

Penelitian-penelitian di bidang multi-supplier telah banyak dilakukan dengan berbagai macam tujuan dan variable keputusan yang digunakan seperti menentukan jumlah pemesanan yang optimum (Sawik [4], Silbermayr dan Minner [6], Song et al. [7], Yin et al. [8], Abginechi et al. [9]), jumlah supplier optimum (Abginehchi et al [9], Guo and Ganeshan [10], dan Geetha and Achary [11]), titik pemesanan ulang optimum (Abginechi et al. [9]). Penelitian ini sejalan dengan penelitian-penelitian di bidang multisupplier yang telah dilakukan, namun berbeda dengan penelitian lain, penekanan pada penelitian ini adalah penjadwalan waktu kedatangan dan kuantitas pengiriman bahan baku pada strategi multi-supplier dengan mempertimbangkan perbedaan nilai parameter dari setiap supplier, kemampuan pasokan dari supplier, dan batasan dari perusahaan serta mempertimbangkan adanya ketidakpastian permintaan. Penelitian diawali dengan penentuan batas minimal inventory untuk menghindari terjadinya stock out akibat ketidakpastian permintaan, yang selanjutnya akan digunakan sebagai parameter dalam melakukan pengembangan model matematika

\section{Metode Penelitian}

Penelitian tentang multi-supplier telah banyak dilakukan dengan tujuan yang berbeda-beda seperti menentukan tingkat safety stock, menentukan jumlah supplier yang optimum, menentukan porsi pemesanan untuk masing-masing supplier, dan mengembangkan model matematika yang dapat digunakan untuk membuat sistem penjadwalan kedatangan serta kuantitas setiap pengiriman dari masing-masing supplier.

Thomas dan Tyworth [5] melakukan kajian pustaka mengenai pooling lead time risk melalui pembagian order (order splitting) ke beberapa supplier. Risetriset di bidang ini secara umum dapat dikategorikan menjadi tiga bidang yaitu riset yang mempelajari tentang efek dari order splitting terhadap effective lead time, riset yang menekankan pada analisis total cost, dan riset yang lebih focus kepada pengurangan cycle stock. Isu utama yang diangkat dalam penelitian ini adalah apakah penghematan dari sisi safety stock holding cost dan shortage cost dapat mengimbangi incremental ordering cost.

Variabel keputusan yang digunakan dalam kasus multi-supplier bervariasi seperti porsi pemesanan setiap supplier, inventory level, jumlah supplier yang optimum, waktu pengiriman barang, dan kuantitas pengiriman barang. Penentuan porsi pemesanan optimum antara lain dilakukan oleh Arda dan Hennet [1]. Arda dan Hennet [1] melakukan penelitian dengan tujuan untuk meminimumkan ratarata biaya penyimpanan dan biaya stockout. Penelitian terfokus pada kondisi stokastik dimana permintaan pelanggan dan lead time dari supplier diasumsikan random. Penelitian tersebut menggunakan complex non-linear function untuk memodelkan biaya yang harus dikeluarkan. Decision variable pada penelitian ini adalah level inventory dan persentase pemesanan kepada masing-masing supplier. Perhitungan level inventory dilakukan dengan mengasumsikan bahwa permintaan pelanggan dan lead time supplier adalah stasioner. Persentase pemesanan ditentukan dengan menggunakan metode Bernoulli Splitting Process dengan Bernoulli branching parameters, dimana persentase optimal 
untuk masing-masing supplier diperoleh ketika sudah tercapai kondisi steady state. Hasil penelitian tersebut menunjukkan bahwa pada kondisi stokastik, penerapan multi-supplier menghasilkan biaya yang lebih rendah jika dibandingkan dengan strategi single-supplier.

Penelitian lain yang menggunakan porsi pemesanan sebagai variabel keputusan dilakukan oleh Chang et al. [12] yang mengembangkan model matematis dengan pendekatan mixed integer untuk menentukan jumlah pemesanan optimal kepada masingmasing supplier. Penentuan jumlah pemesanan optimal ini dilakukan dengan mempertimbangkan variasi lead time, price-quantity discount (PQD), dan keterbatasan sumber daya yang berbeda-beda untuk masing-masing supplier, dengan batasan bahwa stock yang dimiliki harus dapat memenuhi permintaan setiap periode dan tidak melebih batas maksimum kapasitas warehouse. Tujuan yang ingin dicapai dari penelitian ini adalah untuk meminimumkan holding cost dan ordering cost, yang diasumsikan sama untuk setiap supplier. Model mixed integer juga digunakan oleh Lee et al. [13] untuk menentukan lot size yang optimal pada kasus multi-supplier, multi-period, dengan mempertimbangkan adanya quantity discount. Dalam hal ini permintaan dan lead time dari supplier diasumsikan deterministik dan telah diketahui sebelumnya. Meena dan Sarmah [14] mengembangkan model Mixed Integer Non-Linear Programming untuk menentukan optimum alokasi order untuk masingmasing supplier dengan mempertimbangkan perbedaan kapasitas dari masing-masing supplier, kemungkinan kegagalan pengiriman, dan quantity discount. Model diselesaikan dengan menggunakan algoritma genetika. Dalam hal ini permintaan dianggap konstan dan telah diketahui. Song et al. [7] mengembangkan model stokastik dynamic programming untuk menentukan kebijakan persediaan terintegrasi yang mencakup supplier, manufaktur, dan konsumen. Variabel keputusan yang digunakan adalah kuantitas pemesanan dari masing-masing supplier dengan mempertimbangkan batasan kapasitas delivery maksimum dari setiap supplier. Dalam kasus ini, permintaan diasumsikan terdistribusi Poisson, lead time dari setiap supplier terdistribusi eksponensial dengan mean berbeda-beda untuk setiap supplier, dan waktu produksi dari manufaktur diasumsikan terdistribusi eksponensial. State yang digunakan dalam hal ini adalah kedatangan material, completion time dari finished good, dan permintaan konsumen.

Variabel keputusan lain yang sering digunakan dalam kasus multi-supplier adalah menentukan jumlah supplier yang optimum. Beberapa penelitian yang menggunakan variabel keputusan ini antara lain adalah penelitian yang dilakukan oleh Abginehchi et al. [9], Guo and Ganeshan [10], dan Geetha and Achary [11]. Abginehchi et al. [9] menggunakan sistem continuous review policy dimana pada saat reorder point, order dibagi ke dalam $n$ supplier. Untuk menentukan jumlah supplier yang optimal, diasumsikan lead time dan harga dari semua supplier sama. Algoritma Sequential Quadratic Programming digunakan untuk menyelesaikan model yang terbentuk. Guo dan Ganeshan [9] mengembangkan prosedur untuk menentukan jumlah supplier yang harus digunakan sesuai dengan mean dan variance dari lead time yang diinginkan. Geetha dan Achary [10] melanjutkan penelitian yang dilakukan oleh Guo dan Ganeshan [9] dengan mengembangkan prosedur untuk mendapatkan nilai mean dan variance dari lead time. Prosedur yang dikembangkan menggunakan Generalized Lambda Distribution sebagai pendekatan untuk distribusi lead time.

Beberapa penelitian menggunakan jumlah optimum supplier dan kuantitas pemesanannya sebagai variabel keputusan. Silbermayr dan Minner [6] mengembangkan model Semi-Markov Decision Process (SMDP) untuk menentukan jumlah supplier yang digunakan dan jumlah pemesanan untuk masing-masing supplier. Setiap supplier mempunyai karakteristik yang berbeda dalam hal harga, reliability, dan kecepatan pengiriman. Permintaan diasumsikan mengikuti distribusi Poisson. Hasil riset menunjukkan penggunaan multi-supplier menghasilkan total biaya lebih rendah dibandingkan jika hanya menggunakan supplier tunggal. Yin et al. [8] mengembangkan model non-cooperative game (Stackelberg game) untuk menentukan kebijakan produksi, harga, dan persediaan secara simultan dengan permintaan terdistribusi normal. Fungsi tujuan yang digunakan adalah memaksimumkan profit. Dalam model ini, pertama kali perusahaan akan menentukan jumlah produksi, jumlah pemesanan, memilih supplier dan jumlah order untuk setiap supplier. Selanjutnya akan terjadi proses negosiasi antara supplier dan perusahaan untuk menentukan harga jual berdasarkan jumlah kuantitas pemesanannya. Sawik [4] mengembangkan model stokastik mixed integer programming untuk mengintegrasikan pemilihan supplier dan customer order scheduling dengan mempertimbangkan risiko gangguan pasokan. Gangguan pasokan dalam hal ini dapat berupa bencana alam maupun bencana karena perbuatan manusia. Variabel keputusan yang digunakan dalam model ini adalah supplier yang dipilih, orderto-period assignment, dan jumlah pemesanan untuk setiap supplier. Model ini menggunakan medium term planning horizon. Berdasarkan supplier yang ditentukan dan jumlah pemesanan untuk masing- 
masing supplier, selanjutnya digunakan untuk menyusun optimal production schedule untuk memenuhi customer order yang akan meminimumkan biaya.

Penentuan level inventory optimum sebagai variabel keputusan digunakan dalam penelitian yang dilakukan oleh Arda dan Hennet [1] dan Osman dan Demirli [7]. Penelitian yang dilakukan oleh Osman dan Demirli [7] bertujuan untuk mencari safety stock terintegrasi pada supply chain dengan beberapa stockpoint. Perhitungan safety stock pada kondisi stokastik tersebut dengan mempertimbangkan adanya variasi demand dan variasi lead time dari setiap supplier. Untuk parameter lead time, digunakan pendekatan maximum yang diperoleh melalui konsep order statistics. Lead time dari setiap supplier diasumsikan independent, serta identik dan terdistribusi normal. Untuk melakukan perhitungan safety stock, digunakan metode generalized lambda distribution, sehingga diperoleh parameter dari pendekatan maksimum, $E\left(X_{i}\right)$ sebagai mean dan $\operatorname{Var}\left(\mathrm{X}_{\mathrm{i}}\right)$ sebagai variance, untuk $n$ supplier. Tujuan yang ingin dicapai dari penelitian ini adalah untuk dapat memenuhi customer service level dengan biaya pengadaan safety stock minimum.

Model penjadwalan supplier untuk menentukan waktu kedatangan supplier dilakukan antara lain oleh Hum et al. [15]. Hum et al. [15] mengembangkan model matematika untuk membuat penjadwalan multi-supplier pada sebuah perusahaan perakitan komputer. Penjadwalan pengiriman termasuk dalam NP-hard problem dengan tujuan meminimumkan rata-rata level inventory, dengan batasan yang digunakan adalah pattern waktu pengiriman yang berbeda dari setiap supplier dan batas minimal inventory di warehouse atau protection level. Masing-masing supplier memiliki kapasitas pengiriman dan lead time yang berbedabeda. Setiap supplier juga memiliki interval waktu antar pengiriman yang berbeda-beda. Proporsi pemesanan untuk masing-masing supplier sudah ditentukan sebelumnya. Kapasitas setiap pengiriman yang sudah ditentukan oleh setiap supplier, maka variabel keputusan untuk penelitian ini adalah waktu pengiriman dari setiap supplier. Penelitian tersebut juga memperlihatkan hubungan antara level inventory maksimum, rata-rata, dan minimum, untuk menunjukkan bahwa permasalahan penjadwalan pengiriman adalah sama dengan classical inventory staggering problem. Penelitian ini lebih memperhatikan pada terbatasnya kapasitas warehouse, sehingga perlu dilakukan penjadwalan kedatangan bahan baku dari supplier untuk menghindari terjadinya overcapacity. Riezebos dan Zhu [16] mengembangkan prosedur untuk menyusun MRP untuk kondisi multi-supplier dengan mempertimbangkan perbedaan lead time antar supplier dan kemungkinan order crossover, yaitu ketika kedatangan order tidak sesuai dengan urutan pemesanannya. Dalam penelitian ini, optimal $(s, S)$ policy dikembangkan dengan menggunakan model dynamic programming.

Berdasarkan beberapa tinjauan pustaka tersebut, banyak penelitian terkait penjadwalan masih menggunakan asumsi nilai parameter yang sama untuk setiap supplier. Sebagai contoh, Osman dan Demirli [16], Arda dan Hennet [1], Abginehchi et al. [9] menggunakan asumsi lead time yang sama untuk setiap supplier. Demikian juga Arda dan Hennet [1], Hum et al. [15] menggunakan asumsi harga yang sama untuk setiap supplier. Osman dan Demirli [16] dan Guo and ganeshan [10] tidak mempertimbangkan harga dari masing-masing supplier di dalam model yang dikembangkan. Meskipun demikian, beberapa penelitian telah mempertimbangkan adanya perbedaan parameter dari setiap supplier. Guo dan Ganeshan [10], Hum et al. [15], dan Chang et al. [12] telah mengakomodasi adanya variasi lead time dari setiap supplier di dalam modelnya. Selain mempertimbangkan variasi lead time, Chang et al. [12] juga mempertimbangkan adanya variasi harga dari setiap supplier.

Penentuan variabel keputusan dan parameter yang digunakan dalam model sangat tergantung pada kondisi perusahaan. Penelitian ini akan mengembangkan model penjadwalan kedatangan order dari supplier untuk meminimumkan total biaya dengan variabel keputusan waktu kedatangan order dan kuantitas pengiriman dari masing-masing supplier dengan mempertimbangkan variasi lead time dan harga dari masing-masing supplier, kemampuan pasokan dari supplier, batasan sumber daya perusahaan (kapasitas gudang dan syarat batas minimum inventory), serta ketidakpastian permintaan.

\section{Deskripsi Sistem}

Objek yang digunakan sebagai dasar pengembangan model dalam penelitian ini adalah sistem supply chain sebuah perusahaan multi-nasional yang menerapkan strategi multi-supplier untuk memenuhi kebutuhan bahan bakunya. Masing-masing supplier memiliki porsi atau total jumlah pemesanan yang berbeda, dimana setiap porsi tersebut sudah ditentukan sebelumnya melalui kontrak. Selain porsi pemesanan yang berbeda, masing-masing supplier juga memiliki parameter yang berbeda-beda yang meliputi harga per ton bahan baku, jenis kontrak, lot size, waktu shipping terkait dengan negara asal supplier, serta perjanjian status inventory pada tahap shipping atau Good in Transport. Permintaan terhadap bahan baku dan lead time dari masingmasing supplier bersifat stokastik. 
Seluruh bahan baku berasal dari luar negeri. Terdapat dua jenis kontrak yang digunakan oleh supplier, yaitu Estimate to Delivery (ETD) dan Estimate to Arrive (ETA). Supplier yang menerapkan kontrak ETD akan menghitung total jumlah pesanan bahan baku dari seluruh order menggunakan waktu pengiriman bahan baku atau keberangkatan pesanan dari port asal. Supplier yang menerapkan kontrak ETA akan menghitung total jumlah pesanan bahan baku dari seluruh order menggunakan waktu tiba bahan baku di port tujuan, yang berada di Semarang, Indonesia. Berikut adalah tahapan yang dilakukan dalam proses pemesanan bahan baku adalah: (1) Pembuatan dan pengiriman Purchase Order (PO) kepada supplier yang berisi permintaan pengiriman suatu jenis bahan baku dalam jumlah tertentu. Waktu pengiriman PO disebut dengan PO Issued dan setiap PO yang dibuat akan disertai dengan ETA Request, yaitu permintaan waktu kedatangan bahan baku di port tujuan, di Semarang, Indonesia. (2) Pemberian konfirmasi oleh pihak supplier terkait penerimaan PO. (3) Pemberian konfirmasi oleh pihak supplier terkait waktu pengiriman bahan baku dari port negara asal (ETD confirmed) dan perkiraan waktu kedatangan di port negara tujuan (ETA confirmed).

Setelah proses pemesanan, terdapat beberapa proses yang dilewati oleh bahan baku, meliputi pengiriman dan pengendalian kualitas hingga menjadi bahan baku siap pakai. Sesuai perjanjian antara supplier dan perusahaan, hampir seluruh bahan baku yang berada dalam proses pengiriman sudah menjadi inventory milik perusahaan, sehingga waktu pengiriman juga menjadi pertimbangan perusahaan dalam melakukan penjadwalan pengiriman pasokan bahan baku karena akan berpengaruh pada tied up capital cost yang harus ditanggung perusahaan. Beberapa tahapan yang dilalui bahan baku selama proses pengiriman dan pengelolaan adalah: (1) Shipping, yaitu proses pengiriman bahan baku dari negara asal supplier ke negara tujuan perusahaan melalui jalur laut. Durasi shipping untuk setiap pengiriman sangat bergantung pada negara asal supplier dan kondisi cuaca. Pada proses ini, status bahan baku tergantung dari kesepakatan antara supplier dan perusahaan, apakah masih menjadi inventory supplier atau sudah menjadi inventory perusahaan. (2) Customs Clearance (CC), yaitu proses yang dilakukan di port negara tujuan terkait dengan penerimaan barang impor. (3) Quality Inspection (QI), yaitu inspeksi kualitas yang dilakukan oleh QI Department dari perusahaan. (4) Bahan baku akan menjadi ready stock inventory setelah dinyatan lolos Quality Inspection, sedangkan bahan baku yang tidak lolos QI akan diajukan klaim ke pihak supplier untuk selanjutnya dimusnahkan. Ready stock inventory bahan baku ini yang kemudian digunakan untuk proses produksi.

\section{Tahapan Penelitian}

Pengembangan model diawali dengan melakukan deskripsi sistem dari objek yang diteliti. Berdasarkan deskripsi sistem tersebut selanjutnya dibangun model matematika untuk menjadwalkan kedatangan supplier dan kuantitas setiap pengiriman dari masing-masing supplier. Salah satu batasan yang digunakan dalam model adalah jumlah minimum level inventory (safety stock) yang digunakan untuk mengakomodasi ketidakpastian permintaan dan lead time dari masing-masing supplier. Sesuai dengan kebijakan perusahaan, level minimum inventory tersebut tidak dinyatakan dengan kuantitas bahan baku melainkan dalam perkiraan durasi waktu yang diperlukan untuk menghabiskan bahan baku tersebut yang diistilahkan dengan safety time. Oleh karena itu, sebelum model dijalankan, safety time harus ditentukan terlebih dahulu. Apabila hasil perhitungan masih menunjukkan posisi persediaan ada yang berada di bawah safety time yang ditentukan, maka nilai safety time akan dievaluasi sampai posisi inventory tidak ada yang berada di bawah safety time. Safety time pada kondisi ini disebut sebagai safety time optimal. Nilai safety time optimal ini yang selanjutnya digunakan untuk menyusun jadwal dan kuantitas bahan baku pada setiap pengiriman dari setiap supplier.

\section{Model Matematika}

Luaran yang diharapkan dari model matematika ini adalah penjadwalan kedatangan dan kuantitas pengiriman bahan baku dari setiap supplier setiap minggunya dengan mempertimbangkan perbedaan nilai parameter dari setiap supplier dan batasan yang ditentukan oleh perusahaan. Parameter supplier meliputi total jumlah kontrak pemesanan, lot size pengiriman, lead time pengiriman, serta harga yang diberikan masing-masing supplier. Selain perbedaan nilai parameter dari setiap supplier, terdapat batasan dari sisi perusahaan meliputi kapasitas warehouse dan batas minimal inventory di warehouse.

Fungsi tujuan yang digunakan adalah meminimumkan biaya inventory, dimana di dalamnya terdapat komponen purchasing cost, tied up capital cost, dan handling cost. Adanya komponen purchasing cost dan tied up capital cost menyebabkan harga bahan baku yang berbeda dari setiap supplier menjadi hal yang harus dipertimbangkan dalam menentukan waktu kedatangan dan kuantitas pengiriman pasokan bahan baku. Perbedaan harga akan menghasilkan perbedaan biaya pembelian untuk bahan baku 
dari supplier yang berbeda sehingga akan berpengaruh pada perhitungan purchasing cost. Dalam perhitungan tied up capital cost, perbedaan harga akan menghasilkan perbedaan jumlah modal yang tersimpan dalam bentuk inventory yang dimiliki perusahaan

\section{Notasi}

Berikut adalah indeks variable dan parameter dari model matematika yang dikembangkan.

$\begin{array}{ll}I & : \text { set supplier bahan baku } \\ i & : \text { indeks supplier }(i \in I) \\ J & : \text { set satuan waktu penjadwalan } \\ j & : \text { nomor waktu penjadwalan }(j \in J) \\ P & : \text { set harga bahan baku dari supplier } \\ p_{i} & : \text { harga bahan baku dari supplier } i\left(p_{i} \in P\right) \\ K & : \text { set total jumlah pemesanan setiap supplier } \\ k_{i} & : \text { total jumlah pemesanan untuk supplier } i \\ & \quad\left(k_{i} \in K\right) \\ L & : \text { set lot size pengiriman setiap supplier } \\ l_{i} & : \text { lot size pengiriman dari supplier } i\left(l_{i} \in L\right) \\ D & : \text { set demand setiap satuan waktu penjad- } \\ & \quad \text { walan } \\ d_{j} & : \text { demand pada waktu } j\left(d_{j} \in D\right) \\ o_{j} & : \text { sisa stock pada waktu } j \\ m_{j} & : \text { total material handling pada waktu } j \\ b & : \text { persentase untuk tied up capital cost } \\ h & : \text { handling cost dengan batasan maksimal }\end{array}$

$h \quad$ : handling cost dengan batasan maksimal jumlah material handling (handling cost merupakan fixed cost sampai dengan batas maksimalnya, selebihnya dikenakan penalty untuk setiap kelebihannya)

$g \quad$ : maksimal jumlah material handling

$c \quad:$ charge untuk handling cost

$w \quad$ : kapasitas warehouse

$y \quad$ : jumlah minimal inventory (dikonversi dari nilai safety time)

$x \quad$ : kelipatan lot size

$E\left(x_{i}\right) \quad:$ mean lead time untuk $n$ supplier

$\operatorname{Var}\left(X_{i}\right)$ : variance dari lead time $n$ supplier

$\mu \quad$ : mean dari lead time masing-masing supplier

$\sigma \quad$ : standar deviasi lead time dari masingmasing supplier

$m_{i} \quad$ : parameter order statistics untuk $E\left(X_{i}\right)$

$v_{i} \quad$ : parameter order statistics untuk Var $\left(X_{i}\right)$

$C_{r} \quad$ : fungsi untuk perhitungan mi

$\beta(x, y)$ : fungsi beta untuk perhitungan vi

$\mu_{D} \quad$ : rata-rata pemintaan

$\sigma_{D} \quad$ : standar deviasi permintaan

variabel keputusan yang digunakan adalah:

$q_{i j} \quad$ : kuantitas pasokan bahan baku yang dikirim oleh supplier $i$ pada waktu $j$

\section{Fungsi Tujuan}

Fungsi tujuan yang digunakan dalam model ini adalah meminimumkan biaya inventory yang meliputi purchasing cost $(P C)$, opportunity cost $(O C)$ sebagai akibat dari penyimpanan modal dalam bentuk inventory, dan handling cost (HC) seperti ditunjukkan pada persamaan (1). Persamaan (2) sampai dengan persamaan (6) menunjukkan perhitungan untuk masing-masing komponen biaya inventory.

$\min T C=P C+O C+H C$

$P C=\sum_{i=1}^{I} \sum_{j=1}^{J}\left(q_{i j} \times p_{i}\right)$

$o_{j}=o_{j-1}+\sum_{i=1}^{I} q_{i j}-d_{j}$

$O C=\sum_{j=1}^{J}\left(o_{j} \times \sum_{i=1}^{I} p_{i} / I\right) \times b$

Persamaan (2) menunjukkan perhitungan untuk komponen purchasing cost, sedangkan persamaan (3) menunjukkan perhitungan untuk komponen tied up capital cost, yang dipengaruhi oleh sisa stok bahan baku pada waktu $j\left(o_{j}\right)$, harga rata-rata bahan baku dari supplier, dan persentase untuk tied up capital cost (b).

Pada penelitian ini, handling cost menggunakan asumsi fixed cost dengan batasan maksimal jumlah material handling (g) dan akan dikenakan charge (c) untuk setiap kelebihan jumlah material handling. Perhitungan material handling ditunjukkan pada persamaan (5) dan perhitungan handling cost ditunjukkan pada persamaan (6).

$m_{j}=o_{j-1}+\sum_{i=1}^{I} q_{i j}$

$H C=h+\sum_{j=1}^{J}\left(\max \left(m_{j}-g, 0\right) \times c\right)$

\section{Batasan}

Batasan dari setiap supplier adalah jumlah total pesanan selama satu periode, yang ditunjukkan pada persamaan (7), dan lot size setiap pengiriman, yang ditunjukkan pada persamaan (8), dimana nilai $q_{i j}$ dan $x$ harus bernilai non-negative dan integer (persamaan (9) dan persamaan (10)).

$\sum_{j=1}^{J} q_{i j}=k_{i} ; \forall i \in I$

$q_{i j}=x \times l_{i} ; \forall i \in I$

$q_{i j} \geq 0$, integer $; \forall i \in I, j \in J$

$x \geq 0$, integer

Dari sisi perusahaan, penentuan decision variable dipengaruhi oleh batasan kapasitas warehouse dan batas minimal inventory setiap waktu. Batasan kapasitas warehouse dihitung dengan menggunakan indikator jumlah material handling setiap waktu, yang ditunjukkan pada persamaan (11), sedangkan batas minimal inventory dihitung dengan menggunakan indikator sisa stock, yang ditunjukkan pada persamaan (12). 
$m_{j} \leq w ; \forall j \in J$

$o_{j} \geq y ; \forall j \in J$

\section{Penentuan safety time}

Safety time digunakan sebagai batas minimal inventory untuk mengantisipasi adanya variasi demand selama lead time dan dalam kasus ini lead time juga tidak tentu. Untuk strategi multi-supplier, variasi lead time dari beberapa supplier juga harus dipertimbangkan. Salah satu metode yang dapat digunakan adalah metode generalized lambda distribution untuk mendapatkan mean dan variance dengan pendekatan maksimum. Metode ini digunakan untuk lead time dari $n$ supplier yang terdistribusi normal dan identik dengan mean $\mu$ dan variance $\sigma^{2}$. Parameter yang digunakan adalah $\lambda_{1}$, $\lambda_{2}, \lambda_{3}$, dan $\lambda_{4}$ sehingga diperoleh $E\left(X_{i}\right)$ sebagai mean dan $\operatorname{Var}\left(X_{i}\right)$ sebagai variance dari lead time $n$ supplier (Osman dan Demirli [16]). Secara teoretis, expected lead time ditentukan dengan menggunakan persamaan-persamaan berikut.

$$
\begin{aligned}
& E\left(X_{i}\right)=\mu+\sigma m_{i} \\
& m_{i}=\frac{C_{i}-C_{n-i+1}}{\lambda_{2} C_{n+1}}
\end{aligned}
$$

dimana

$$
\begin{aligned}
& C_{r}=r \prod_{k=1}^{r}\left(1+\frac{\lambda_{3}-1}{k}\right) \operatorname{Var}\left(X_{i}\right)=\sigma^{2} v_{i} \\
& v_{i}=\frac{\beta\left(2 \lambda_{3}+1, t\right)-2 \beta\left(\lambda_{3}+i, t+\lambda_{4}\right)+\beta\left(i, t+2 \lambda_{4}\right)}{\lambda_{2}^{2} \beta(i, t)}-\left(m_{i}-\lambda_{1}\right)^{2}
\end{aligned}
$$

dimana

$$
\begin{aligned}
& t=n-i+1 \\
& \operatorname{dan} \beta(x, y)=\frac{(x-1) !(y-1) !}{(x+y-1) !}
\end{aligned}
$$

Nilai safety stock (dalam hal ini juga berlaku sebagai jumlah minimal inventory, y) dan safety time selanjutnya ditentukan dengan menggunakan persamaan (16) dan persamaan (17).

$$
\begin{aligned}
& y=\mu_{D} \times E\left(X_{i}\right)+z \sqrt{E\left(X_{i}\right) \times \sigma_{D}^{2}+\mu_{D} \times \operatorname{Var}\left(X_{i}\right)} \\
& \text { safety time }=\frac{y}{\mu_{D}}
\end{aligned}
$$

\section{Hasil dan Pembahasan}

\section{Studi Kasus}

Seperti telah dijelaskan sebelumnya, penelitian ini menggunakan sebuah perusahaan multinasional yang memproduksi berbagai jenis produk nutrisi sebagai objek penelitian. Model matematika yang telah dikembangkan selanjutnya diaplikasikan untuk menentukan safety time optimum dan penjadwalan kedatangan serta kuantitas pengiriman dari setiap supplier untuk beberapa bahan baku utamanya. Pada penelitian ini, studi kasus akan difokuskan pada 3 jenis bahan baku dairy yang memiliki porsi dan membutuhkan biaya paling besar, yaitu bahan baku A, B, dan C. Sebagai bahan baku utama yang dibutuhkan untuk produksi setiap harinya, ketiga bahan baku tersebut tidak boleh mengalami stockout karena dapat menghentikan proses di lantai produksi. Namun, penyimpanan persediaan bahan baku tersebut juga dibatasi oleh kapasitas warehouse, kontrak yang telah disepakati antara supplier dan perusahaan, serta kemampuan supplier dalam memenuhi pesanan dari perusahaan.

Untuk memenuhi kebutuhan ketiga bahan baku tersebut, perusahaan menerapkan strategi multisupplier, dimana ketiga bahan baku utama tersebut berturut-turut memiliki 3 supplier, 2 supplier, dan 4 supplier. Masing-masing supplier memiliki porsi atau total jumlah pemesanan yang berbeda, dimana setiap porsi tersebut sudah ditentukan sebelumnya melalui kontrak. Selain porsi pemesanan yang berbeda, masing-masing supplier juga memiliki parameter yang berbeda-beda yang meliputi harga per ton bahan baku, jenis kontrak, lot size, waktu shipping terkait dengan negara asal supplier, serta perjanjian status inventory pada tahap shipping atau Good In Transport. Tabel 1 menunjukkan parameter yang digunakan dalam model untuk setiap supplier. Berikut definisi dari masing-masing parameter. (1) Porsi atau total jumlah pemesanan adalah total jumlah bahan baku yang dapat dipesan kepada supplier dalam jangka waktu satu quarter. (2) Harga untuk per ton bahan baku yang dipesan kepada supplier, dimana didalamnya sudah terdapat unsur ordering cost, sehingga proses pemesanan yang dilakukan perusahaan tidak lagi mempertimbangkan adanya ordering cost. Dalam penelitian ini, harga bahan baku dalam mata uang $\$$ dan $€$ dikonversi ke dalam mata uang Rp menggunakan kurs tengah Bank Indonesia pada tanggal 28 Februari 2014, yaitu Rp 11.634,00 per 1 \$ dan Rp $15.945,00$ per $1 €$. (3) Jenis kontrak adalah parameter supplier terkait dengan periode perhitungan total jumlah pesanan bahan baku dari perusahaan, untuk kemudian dievaluasi dengan porsi pemesanan per quarter dari masing-masing supplier. Terdapat dua jenis kontrak yang digunakan oleh supplier, yaitu Estimate to Delivery (ETD) dan Estimate to Arrive (ETA). (4) Lot size adalah kelipatan jumlah yang ditetapkan oleh setiap supplier untuk setiap pengiriman bahan baku. (5) Waktu shipping adalah durasi bahan baku ketika dalam perjalanan menempuh jalur laut dalam proses pengiriman dari port asal hingga port tujuan, dimana waktu shipping ini bergantung pada negara asal dari supplier bahan baku. Waktu shipping diasumsikan mengikuti distribusi normal sehingga 
Tabel 1. Parameter untuk setiap supplier bahan baku (data perusahaan)

\begin{tabular}{|c|c|c|c|c|c|c|c|c|c|c|}
\hline \multirow{2}{*}{$\begin{array}{c}\text { Bahan } \\
\text { baku }\end{array}$} & \multirow{2}{*}{ Supplier } & \multirow{2}{*}{$\begin{array}{c}\text { Negara } \\
\text { asal }\end{array}$} & \multirow{2}{*}{$\begin{array}{c}\text { Porsi } \\
\text { kontrak } \\
\text { (ton) }\end{array}$} & \multicolumn{2}{|c|}{ Harga per ton } & \multirow{2}{*}{$\begin{array}{c}\text { Jenis } \\
\text { kontrak }\end{array}$} & \multirow{2}{*}{$\begin{array}{l}\text { Lot size } \\
\text { (ton) }\end{array}$} & \multicolumn{2}{|c|}{ Durasi shipping } & \multirow{2}{*}{$\begin{array}{c}\text { Status } \\
\text { inventory } \\
\text { GIT }\end{array}$} \\
\hline & & & & USD & EUR & & & Rata-rata & Std dev & \\
\hline \multirow{3}{*}{$\mathrm{A}$} & $\mathrm{A} 1$ & $\begin{array}{c}\text { New } \\
\text { Zealand }\end{array}$ & 3.200 & $\$ 4.704,05$ & - & ETA & 25 & 26 & 5 & Perusahaan \\
\hline & A2 & Australia & 1.200 & $\$ 4.086,97$ & - & ETD & 25 & 22 & 2 & Perusahaan \\
\hline & A3 & $\begin{array}{c}\text { New } \\
\text { Zealand }\end{array}$ & 700 & $\$ 4.311,14$ & - & ETD & 25 & 23 & 3 & Perusahaan \\
\hline \multirow{2}{*}{ B } & B1 & Prancis & 1.500 & $\$ 1.709,17$ & - & ETD & 25 & 43 & 4 & Supplier \\
\hline & $\mathrm{B} 2$ & Prancis & 288 & - & $€ 1.164,17$ & ETD & 24 & 39 & 3 & Perusahaan \\
\hline \multirow{4}{*}{$\mathrm{C}$} & C1 & US & 1.250 & $\$ 3.296,52$ & - & ETA & 20 & 29 & 4 & Perusahaan \\
\hline & $\mathrm{C} 2$ & US & 500 & $\$ 3.415,70$ & - & ETD & 20 & 36 & 7 & Perusahaan \\
\hline & C3 & Australia & 350 & $\$ 3.487,40$ & - & ETD & 25 & 21 & 3 & Perusahaan \\
\hline & $\mathrm{C} 4$ & Argentina & 1.375 & $\$ 3.339,16$ & - & ETD & 25 & 39 & 5 & Perusahaan \\
\hline
\end{tabular}

parameter yang digunakan adalah rata-rata dan standar deviasi. (6) Perjanjian inventory adalah perjanjian antara supplier dan perusahaan terkait status bahan baku yang sedang berada di perjalanan laut atau shipping, apakah masih menjadi inventory milik supplier atau sudah menjadi inventory milik perusahaan.

Proses pengendalian inventory bahan baku perusahaan dilakukan melalui pantauan jumlah inventory yang dimiliki perusahaan, baik untuk inventory yang sudah maupun belum tiba di warehouse, serta mengevaluasi jumlah inventory tersebut dengan batas minimal inventory setiap waktu. Dalam menentukan batas minimal inventory, perusahaan menggunakan konsep safety time yang mengindikasikan batas minimal inventory yang harus dimiliki perusahaan setiap waktunya. Safety time dinyatakan dengan menggunakan satuan waktu dan ditentukan berdasarkan jumlah kebutuhan bahan baku sesuai MRP selama durasi waktu tertentu.

Setelah proses pemesanan, terdapat beberapa proses yang dilewati oleh bahan baku, meliputi pengiriman dan pengendalian kualitas hingga menjadi bahan baku siap pakai. Berikut adalah beberapa tahapan yang dilalui bahan baku selama proses pengiriman dan pengelolaan beserta nilai yang digunakan di dalam model.

(1) Shipping, dengan durasi untuk setiap pengiriman sangat bergantung pada negara asal supplier dan kondisi cuaca. Pada proses ini, status bahan baku tergantung dari kesepakatan antara supplier dan perusahaan, apakah masih menjadi inventory supplier atau sudah menjadi inventory perusahaan. (2) Customs Clearance (CC). Untuk kasus ini, proses CC dilakukan oleh pihak ketiga yang ditunjuk perusahaan dan diasumsikan membutuhkan waktu 7 hari atau 1 minggu. (3) Quality Inspection (QI). Pada kondisi normal, proses QI membutuhkan waktu 5 hari sedangkan pada kondisi ditemukannya quality issue, proses QI akan membutuhkan waktu lebih lama yaitu sekitar 1 minggu, dengan probabilitas ditemukannya quality issue adalah 3-5\%. (4) Bahan baku akan menjadi ready stock inventory setelah dinyatan lolos Quality Inspection.

Untuk pengelolaan inventory di warehouse, perusahaan menerapkan sistem outsource dengan menunjuk pihak ketiga untuk melakukan material handling di warehouse. Sistem pembayaran yang digunakan adalah biaya kontrak untuk satu tahun. Dalam hal ini, handling cost menjadi biaya tetap per tahun dengan batas maksimal inventory yang dikelola setiap periodenya, yaitu 8500 ton untuk keseluruhan bahan baku, dan akan dikenakan charge untuk setiap ton kelebihan inventory. Pada penelitian ini, handling cost dan batas maksimal inventory untuk masing-masing jenis bahan baku ditentukan berdasarkan persentase porsi terhadap keseluruhan inventory bahan baku.

Dalam melakukan pengendalian inventory bahan baku, perusahaan menggunakan metode gabungan antara continuous review policy dan periodic review policy, dimana jumlah inventory bahan baku dipantau setiap hari dan akan dilakukan pemesanan ketika jumlah inventory berada di bawah batas minimal inventory. Acuan yang digunakan untuk melakukan pengendalian inventory adalah safety time, sebagai batas minimal jumlah inventory yang harus dimiliki oleh perusahaan setiap periode. Dengan acuan safety time, maka batas minimal inventory akan berbeda setiap waktu, tergantung pada kebutuhan bahan baku pada beberapa waktu ke depan.

\section{Optimasi Safety Time}

Safety time digunakan sebagai batas minimal inventory untuk mengantisipasi adanya variasi demand selama lead time. Perhitungan safety time dilakukan dengan mempertimbangkan adanya 
variasi demand bahan baku dan menggunakan asumsi lead time deterministik yang digunakan oleh perusahaan, yaitu 97 hari, dimana 90 hari merupakan durasi produksi bahan baku dan pengiriman melalui jalur laut, sedangkan 7 hari adalah durasi Customs Clearance. Untuk mengakomodasi adanya variasi demand, dilakukan pengujian menggunakan software Stat::fit untuk mengetahui pola distribusi data demand. Hasil pengujian menunjukkan bahwa data demand untuk ketiga bahan baku mengikuti pola distribusi normal. Untuk bahan baku utama, perhitungan safety time menggunakan target service level $99.9 \%$ karena perusahaan tidak mengizinkan terjadinya stockout bahan baku yang akan menyebabkan berhentinya proses produksi.

Pada periodic review policy, pengendalian inventory yang dilakukan menggunakan sebuah parameter, yaitu base-stock level. Perusahaan akan menentukan target level inventory, base-stock level, dan periode review. Level inventory akan ditinjau pada setiap periode, dan order material akan dilakukan setelahnya untuk meningkatkan posisi inventory agar mencapai base-stock level. Base-stock level terdiri dari 2 komponen, yaitu rata-rata demand selama jangka waktu antar periode review dan safety stock. Rata-rata demand antar periode review adalah rata-rata demand selama jangka waktu periode review ditambah lead time.

Menggunakan persamaan (12) sampai dengan persamaan (17), maka diperoleh safety time seperti terdapat pada Tabel 2. Tabel 2 menunjukkan perbandingan antara nilai safety time teoritis dan safety time yang digunakan perusahaan saat ini, Terlihat bahwa safety time yang digunakan perusahaan saat ini sudah sesuai dengan teori. Namun pada kondisi aktual, level inventory pada beberapa periode masih berada di bawah tingkat safety time, meskipun tidak sampai mengalami stockout.

Tabel 2. Perbandingan tingkat safety time aktual dan teoritis

\begin{tabular}{ccccc}
\hline \multirow{2}{*}{$\begin{array}{c}\text { Bahan } \\
\text { baku }\end{array}$} & \multicolumn{2}{c}{ Aktual } & \multicolumn{2}{c}{ Teoretis } \\
\cline { 2 - 5 } & $\begin{array}{c}\text { Safety } \\
\text { time, hari }\end{array}$ & $\begin{array}{c}\text { Safety time, } \\
\text { minggu }\end{array}$ & $\begin{array}{c}\text { Safety time, Safety time, } \\
\text { hari }\end{array}$ & $\begin{array}{c}\text { minggu } \\
\text { ming }\end{array}$ \\
\hline A & 13 & 1,86 & 13 & 1,86 \\
B & 16 & 2,29 & 16 & 2,29 \\
C & 14 & 2,00 & 14 & 2,00 \\
\hline
\end{tabular}

Tabel 3. Perbandingan tingkat safety time aktual dan setelah optimasi

\begin{tabular}{ccccc}
\hline \multirow{2}{*}{$\begin{array}{c}\text { Bahan } \\
\text { baku }\end{array}$} & \multicolumn{2}{c}{ Aktual } & \multicolumn{2}{c}{ Hasil optimasi } \\
\cline { 2 - 5 } & $\begin{array}{c}\text { Safety } \\
\text { time, hari }\end{array}$ & $\begin{array}{c}\text { Safety time, } \\
\text { minggu }\end{array}$ & $\begin{array}{c}\text { Safety time, } \\
\text { hari }\end{array}$ & $\begin{array}{c}\text { Safety time, } \\
\text { minggu }\end{array}$ \\
\hline A & 13 & 1,86 & 10 & 1,43 \\
B & 16 & 2,29 & 11 & 1,57 \\
C & 14 & 2,00 & 10 & 1,43 \\
\hline
\end{tabular}

Hal ini disebabkan tingkat safety time yang diterapkan terlalu tinggi. Safety time yang tinggi sebenarnya memberikan keuntungan seperti memperkecil kemungkinan terjadinya stock out. Namun, safety time yang terlalu tinggi menyebabkan biaya simpan dan tied up capital cost yang ditimbulkan juga semakin tinggi. Mempertimbangkan hal tersebut, maka dilakukan optimasi lebih lanjut terkait tingkat safety time yang dapat diterapkan di perusahaan dengan batasan tidak diperkenankan terjadi stock out dan sepanjang periode level inventory tidak pernah berada di bawah safety time. Optimasi dilakukan dengan menggunakan model yang sudah dibangun namun kali ini dengan safety time sebagai variabel keputusannya. Proses iterasi dihentikan pada saat tidak terdapat periode dimana level inventory berada di bawah tingkat safety time. Tabel 3 menunjukkan perbandingan tingkat safety time aktual dan setelah dilakukan optimasi.

\section{Optimasi Penjadwalan}

Model matematika yang dibangun telah melalui proses verifikasi dan validasi. Pada penelitian ini, validasi dilakukan dengan memastikan seluruh constraints dalam model telah sesuai dengan kondisi yang ada dan dibandingkan dengan penjadwalan yang diterapkan saat ini. Model diselesaikan dengan menggunakan software LINGO 9.0 dengan menggunakan nilai safety time optimal dan dikonversikan dalam bentuk minimum inventory $(y)$ dan parameter model yang telah diberikan. Penjadwalan dilakukan untuk periode satu tahun (52 minggu). Tabel 4 menunjukkan contoh penjadwalan kedatangan material dari masing-masing supplier untuk bahan baku A untuk minggu ke-1 sampai dengan minggu ke-52 hasil output dari LINGO 9.0. Sebagai contoh, pada minggu ke-14 dilakukan pengiriman bahan baku A dari supplier A1 sebanyak 550 ton. Bahan baku ini akan sampai di pelabuhan Semarang pada minggu ke-18 dan selanjutnya akan diproses di Customs Clearance (CC). Waktu yang diperlukan untuk proses CC sekitar 1 minggu. Setelah selesai proses CC, pada minggu ke-19 selanjutnya bahan baku akan menjalani proses Quality Inspection (QI). Apabila lolos QI, maka status bahan baku selanjutnya akan menjadi Stock Release (SR) dan siap digunakna untuk produksi, namun apabila tidak lolos QI, maka bahan baku akan di-reject dan statusnya menjadi OUT. Permintaan setiap minggu berfluktuasi dan mengikuti distribusi normal. Sisa stock ditentukan berdasarkan sisa stock periode sebelumnya, jumlah total stock release, dan demand pada minggu tersebut. Total bahan baku yang harus ditangani merupakan penjumlahan dari sisa stock dan bahan baku yang masih berada pada tahap QI. 
Tabel 4. Hasil optimasi penjadwalan bahan baku A (dalam ton)

\begin{tabular}{|c|c|c|c|c|c|c|c|c|c|c|c|c|c|c|}
\hline \multicolumn{2}{|c|}{ Week } & 1 & 2 & 3 & 4 & 5 & 6 & 7 & 8 & 9 & 10 & 11 & 12 & 13 \\
\hline \multirow{5}{*}{ 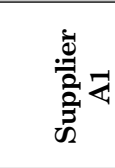 } & SHIP & 0 & 0 & 300 & 425 & 0 & 0 & 0 & 375 & 550 & 0 & 0 & 325 & 325 \\
\hline & $\mathrm{CC}$ & 250 & 450 & 650 & 0 & 0 & 0 & 0 & 300 & 425 & 0 & 0 & 375 & 550 \\
\hline & $\mathrm{QI}$ & 275 & 250 & 450 & 650 & 0 & 0 & 0 & 0 & 300 & 425 & 0 & 0 & 375 \\
\hline & SR & 275 & 250 & 450 & 650 & 0 & 0 & 0 & 0 & 300 & 425 & 0 & 0 & 375 \\
\hline & OUT & 0 & 0 & 0 & 0 & 0 & 0 & 0 & 0 & 0 & 0 & 0 & 0 & 0 \\
\hline \multirow{5}{*}{ 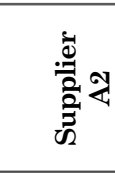 } & SHIP & 0 & 0 & 125 & 0 & 0 & 0 & 0 & 350 & 0 & 525 & 200 & 0 & 0 \\
\hline & $\mathrm{CC}$ & 0 & 0 & 0 & 275 & 0 & 75 & 125 & 0 & 0 & 0 & 350 & 0 & 0 \\
\hline & $\mathrm{QI}$ & 0 & 0 & 0 & 0 & 275 & 0 & 75 & 125 & 0 & 0 & 0 & 350 & 0 \\
\hline & SR & 0 & 0 & 0 & 0 & 275 & 0 & 75 & 125 & 0 & 0 & 0 & 350 & 0 \\
\hline & OUT & 0 & 0 & 0 & 0 & 0 & 0 & 0 & 0 & 0 & 0 & 0 & 0 & 0 \\
\hline \multirow{5}{*}{ 离 } & SHIP & 0 & 0 & 0 & 100 & 100 & 400 & 0 & 0 & 0 & 0 & 0 & 50 & 50 \\
\hline & $\mathrm{CC}$ & 0 & 0 & 0 & 0 & 0 & 0 & 0 & 100 & 100 & 400 & 0 & 0 & 0 \\
\hline & $\mathrm{QI}$ & 0 & 0 & 0 & 0 & 0 & 0 & 0 & 0 & 100 & 100 & 400 & 0 & 0 \\
\hline & SR & 0 & 0 & 0 & 0 & 0 & 0 & 0 & 0 & 100 & 100 & 400 & 0 & 0 \\
\hline & OUT & 0 & 0 & 0 & 0 & 0 & 0 & 0 & 0 & 0 & 0 & 0 & 0 & 0 \\
\hline \multirow{2}{*}{\multicolumn{2}{|c|}{$\begin{array}{l}\text { Demand } \\
\text { Jml_SR }\end{array}$}} & 257,55 & 458,22 & 394,19 & 271,79 & 36,81 & 305,85 & 109,37 & 414,17 & 307,21 & 499,88 & 433,63 & 409,01 & 487,32 \\
\hline & & 275 & 250 & 450 & 650 & 275 & 0 & 75 & 125 & 400 & 525 & 400 & 350 & 375 \\
\hline \multicolumn{2}{|c|}{ Sisa_stock } & 788,69 & 580,47 & 636,28 & 1014,49 & 1252,67 & 946,82 & 912,45 & 623,28 & 716,07 & 741,20 & 707,57 & 648,56 & 536,24 \\
\hline \multicolumn{2}{|c|}{ Min inventory } & 627,72 & 511,06 & 287,62 & 168,33 & 352,88 & 287,46 & 546,27 & 522,16 & 686,34 & 609,50 & 618,56 & 624,58 & 519,94 \\
\hline \multicolumn{2}{|c|}{ Inventory status } & YES & YES & YES & YES & YES & YES & YES & YES & YES & YES & YES & YES & YES \\
\hline \multicolumn{2}{|c|}{ Total_MH } & 1046,24 & 1038,69 & 1030,47 & 1286,28 & 1289,49 & 1252,67 & 1029,49 & 1021,82 & 1023,28 & 1241,08 & 1141,2 & 1057,57 & 1023,56 \\
\hline
\end{tabular}

Tabel 4. Hasil optimasi penjadwalan bahan baku A (Lanjutan)

\begin{tabular}{|c|c|c|c|c|c|c|c|c|c|c|c|c|c|c|}
\hline \multicolumn{2}{|c|}{ Week } & 14 & 15 & 16 & 17 & 18 & 19 & 20 & 21 & 22 & 23 & 24 & 25 & 26 \\
\hline \multirow{5}{*}{ 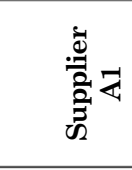 } & SHIP & 550 & 0 & 0 & 0 & 600 & 275 & 0 & 0 & 0 & 0 & 0 & 275 & 500 \\
\hline & $\mathrm{CC}$ & 0 & 0 & 325 & 325 & 550 & 0 & 0 & 0 & 275 & 600 & 0 & 0 & 0 \\
\hline & $\mathrm{QI}$ & 550 & 0 & 0 & 325 & 325 & 550 & 0 & 0 & 0 & 275 & 600 & 0 & 0 \\
\hline & SR & 550 & 0 & 0 & 325 & 325 & 550 & 0 & 0 & 0 & 275 & 425 & 0 & 0 \\
\hline & OUT & 0 & 0 & 0 & 0 & 0 & 0 & 0 & 0 & 0 & 0 & 0 & 600 & 0 \\
\hline \multirow{5}{*}{ 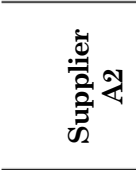 } & SHIP & 0 & 0 & 0 & 425 & 0 & 0 & 0 & 0 & 450 & 0 & 0 & 325 & 0 \\
\hline & $\mathrm{CC}$ & 525 & 200 & 0 & 0 & 0 & 0 & 375 & 425 & 0 & 0 & 0 & 275 & 450 \\
\hline & $\mathrm{QI}$ & 0 & 525 & 200 & 0 & 0 & 0 & 0 & 375 & 425 & 0 & 0 & 0 & 275 \\
\hline & SR & 0 & 525 & 200 & 0 & 0 & 0 & 0 & 375 & 425 & 0 & 0 & 0 & 275 \\
\hline & OUT & 0 & 0 & 0 & 0 & 0 & 0 & 0 & 0 & 0 & 0 & 0 & 0 & 0 \\
\hline \multirow{5}{*}{ 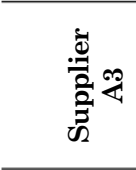 } & SHIP & 0 & 125 & 0 & 0 & 0 & 0 & 250 & 0 & 0 & 325 & 0 & 0 & 0 \\
\hline & $\mathrm{CC}$ & 0 & 0 & 50 & 50 & 0 & 125 & 0 & 0 & 0 & 0 & 250 & 0 & 0 \\
\hline & $\mathrm{QI}$ & 0 & 0 & 0 & 50 & 50 & 0 & 125 & 0 & 0 & 0 & 0 & 250 & 0 \\
\hline & SR & 0 & 0 & 0 & 50 & 50 & 0 & 125 & 0 & 0 & 0 & 0 & 250 & 0 \\
\hline & OUT & 0 & 0 & 0 & 0 & 0 & 0 & 0 & 0 & 0 & 0 & 0 & 0 & 0 \\
\hline \multicolumn{2}{|c|}{ Demand } & 319,20 & 466,84 & 369,45 & 372,99 & 296,26 & 376,90 & 376,48 & 415,01 & 265,94 & 347,69 & 327,64 & 281,46 & 441,73 \\
\hline \multicolumn{2}{|c|}{ Jml_SR } & 550 & 525 & 200 & 375 & 375 & 550 & 125 & 375 & 425 & 275 & 425 & 250 & 275 \\
\hline \multicolumn{2}{|c|}{ Sisa_stock } & 767,04 & 825,20 & 655,75 & 657,76 & 736,50 & 909,60 & 658,12 & 618,11 & 777,17 & 704,48 & 801,85 & 770,38 & 603,65 \\
\hline \multicolumn{2}{|c|}{ Min inventory } & 625,70 & 529,84 & 500,38 & 458,33 & 538,78 & 554,93 & 529,37 & 415,44 & 488,57 & 448,66 & 471,41 & 585,59 & 477,36 \\
\hline \multicolumn{2}{|c|}{ Inventory status } & YES & YES & YES & YES & YES & YES & YES & YES & YES & YES & YES & YES & YES \\
\hline \multicolumn{2}{|c|}{ Total_MH } & 1086,24 & 1292,04 & 1025,20 & 1030,75 & 1032,76 & 1286,501 & 1034,601 & 1033,12 & 1043,11 & 1052,17 & 1304,48 & 1051,85 & 1045,38 \\
\hline \multicolumn{15}{|c|}{ Keterangan simbol: } \\
\hline SHIP & \multicolumn{14}{|c|}{$=$ Jumlah bahan baku yang dikirimkan } \\
\hline $\mathrm{CC}$ & \multicolumn{14}{|c|}{$=$ Customs Clearance } \\
\hline QI & \multicolumn{14}{|c|}{$=$ Quality Inspection } \\
\hline SR & \multicolumn{14}{|c|}{$=$ Stock Release } \\
\hline OUT & \multicolumn{14}{|c|}{$=$ Material yang tidak lolos QI } \\
\hline Jml_SR & \multicolumn{14}{|c|}{$=$ Jumlah total stock release dari ke-3 supplier } \\
\hline TOTAL_ & $=\mathrm{T}$ & materia & andling & mlah to & l bahan & Noки уан. & g harus $\mathrm{c}$ & dikelola) & & & & & & \\
\hline
\end{tabular}

Pada status inventory, status "yes" menunjukkan bahwa jumlah inventory yang dimiliki berada di atas batas minimal inventory, sedangkan status "no" menunjukkan bahwa jumlah inventory yang dimiliki berada di bawah batas minimal inventory.

Dari hasil penjadwalan yang diperoleh, didapatkan total biaya inventory untuk masing-masing bahan baku yang ditunjukkan pada Tabel 5. Meskipun total biaya inventory yang dikeluarkan perusahaan saat ini tidak dapat ditampilkan dalam makalah ini karena merupakan rahasia perusahaan, namun berdasarkan evaluasi bersama dengan pihak perusahaan dapat disimpulkan bahwa total biaya inventory model lebih rendah daripada total biaya inventory yang dikeluarkan perusahaan saat ini. Apabila dievaluasi lebih lanjut, terdapat perbedaan antara hasil penjadwalan yang diperoleh dengan penjadwalan yang dilakukan perusahaan saat ini yang menyebabkan perbedaan biaya inventory yang dikeluarkan. Pada sistem nyata, pemesanan cenderung dilakukan dalam jumlah kecil namun dengan frekuensi tinggi, sehingga pemesanan bahan baku lebih tersebar dalam beberapa periode. 
Pada hasil penjadwalan berdasarkan model, pemesanan cenderung dilakukan dalam jumlah yang lebih besar karena pola inilah yang memungkinkan untuk mendapatkan total biaya inventory yang rendah. Sebagai perbandingan, frekuensi kedatangan material saat ini sebanyak 88 kali dalam setahun, sedangkan berdasarkan model sebanyak 59 kedatangan. Selain itu, safety time yang digunakan di model juga lebih rendah daripada safety time yang digunakan oleh saat ini. Pengaruh perbedaan penggunaan safety time ini terlihat dari rata-rata sisa stock tiap minggunya. Rata-rata sisa stock berdasarkan model sebesar 781,24 ton per minggu, sedangkan rata-rata sisa stock saat ini sebesar 1613,48 ton per minggu. Hal ini berpengaruh terhadap besarnya biaya inventory dan opportunity cost sebagai akibat dari penyimpanan modal dalam bentuk inventory, dan handling cost meskipun besaran handling cost dalam kasus ini relatif kecil dibandingkan dengan purchasing cost dan opportunity cost (tied up capital cost). Sistem pemesanan yang dilakukan oleh perusahaan mempunyai kecenderungan menggunakan pola pengalaman dan pengulangan dalam melakukan pemesanan oleh perusahaan untuk membangun hubungan jangka panjang dengan supplier, dimana pola ini belum digunakan sebagai batasan pada model yang dibangun.

\section{Simpulan}

Penelitian ini membangun model matematika untuk menentukan waktu kedatangan dan kuantitas pengiriman dari beberapa supplier, dengan mempertimbangkan ketidakpastian permintaan dan lead time dari setiap supplier serta batasan dari perusahaan terkait batas maksimal material handling dan batas minimal inventory (dinyatakan dengan safety time) yang ada di warehouse. Setiap supplier mempunyai parameter yang berbeda terkait harga, lot size, nilai kontrak (total jumlah pesanan), dan jenis kontrak. Hasil studi kasus menunjukkan bahwa model yang dibangun telah dapat digunakan untuk menentukan optimum safety time dengan mempertimbangkan fluktuasi permintaan dan selanjutnya nilai safety time optimum tersebut digunakan untuk menghasilkan jadwal kedatangan dan kuantitas bahan baku dengan total biaya inventory yang lebih rendah dari total biaya saat ini.

Terdapat beberapa penelitian lanjutan yang akan dilaksanakan. Pertama, dalam penelitian ini jumlah supplier beserta jumlah total pengirimannya selama setahun telah ditentukan berdasarkan target produksi tahunannya. Penelitian selanjutnya akan menentukan jumlah supplier optimum beserta kuantitas pemesanan optimum dari setiap supplier. Kedua, penjadwalan supplier dan kuantitas pengirimannya akan diintegrasikan dengan penjadwalan produksi.

\section{Daftar Pustaka}

1. Arda, Y., and Hennet, J.C., Inventory Control in a Multi-Supplier System, International Journal Production Economics, 104(2), 2006, pp. 249-259.

2. Ganeshan, R., managing Supply Chain Inventories: A Multiple Retailer, One Warehouse, Multiple Supplier Model, International Journal Production Economics, 59, 1999, pp. 341-354.

3. Minner, S., Multiple-Supplier Inventory Models in Supply Chain Management: A Review, International Journal Production Economics, 81-82, 2003, pp. 265-279.

4. Sawik, T., Joint Supplier Selection and Scheduling of Customer Orders under Disruption Risks: Single vs Dual Sourcing, Omega, 43, 2014, pp 83-95.

5. Thomas, D.J., and Tyworth, J.E., Pooling LeadTime Risk by Order Splitting: A Critical Review, Transportation Research Part E, 42, 2006, pp. 245-257.

6. Silbermayr, L., and Minner, S., A Multiple Sourcing Inventory Model under Disruption Risk, International Journal Production Economics, 149, 2014, pp.47-46.

7. Song, D.P., Dong, J.X., and Xu, J., Integrated Inventory Management and Supplier Base Reduction in A Supply Chain with Multiple Uncertainties, European Journal of Operational Research, 232, 2014, pp. 522-536.

8. Yin, S., Nishi, T., and Grossmann, I.E., Optimal Quantity Discount Coordination for Supply Chin Optimization with One Manufacturer and Multiple Suppliers under Demand Uncertainties, The International Journal of Advanced Manufacturing Technology, 76, 2015, pp. 1173-1184.

9. Abginehchi, S., Farahani, R.Z., and Rezapour, S., A Mathematical Model for Order Splitting in A Multi-Supplier Single-Item Inventory System, Journal of Manufacturing Systems, 32, 2013, pp. 55-67.

10. Guo, Y., and Ganeshan, R., Are More Supplier Better?, Journal of the Operational Research Society, 46, 1995, pp. 892-895.

11. Geetha, K.K. and Achary, K.K., Are More Suppliers Better?: Generalizing the Guo and Ganeshan Procedure, Journal of the Operational Research Society, 51. 2000, pp.1179-1183.

12. Chang, C.T., Chin, C.L., and Lin, M.F., On the Single Item Multi-Supplier System with Variable Lead-Time, Price-Quantity Discount, and Resource Constraints, Applied Mathematics and Computation, 182, 2006, pp.89-97.

13. Lee, A.H.I., Kang, H.Y., Lai, C-M., and Hong, W.Y., An Integrated Model for Lot Sizing With Supplier Selection and Quantity Discounts, 
Applied Mathematical Modelling, 37, 2013, pp. 4733-4746.

14. Meena, P.L., and Sarmah, S.P., Multiple Sourcing under Supplier Failure Risk and Quantity Discount: A Genetic Algorithm Approach, Transportation Research Part E, 50, 2013, pp. 84-97
15. Hum, S. H., Sharafali M., and Teo, C. P., Staggering Periodic Replenishment in Multivendor JIT Environments, Operations Research, 53(4), 2005, pp. 698-710.

16. Osman, H., dan Demirli, K., Integrated Safety Stock Optimization for Multiple Sourced Stockpoints Facing Variable Demand and Lead Time, International Journal Production Economics, 135, 2012, pp. 299-307 